\title{
The Cultural Dimension of School Libraries in a Knowledge Society
}

\author{
Tom Jorgensen \\ Centre for Children's Literature, \\ The Danish University of Education \\ Emdrupvej 10 \\ DK 2400 Copenhagen NV \\ Denmark \\ tomj@dpb.dpu.dk
}

\begin{abstract}
My research project concerns the cultural dimension of the Danish school library. It consists partly of a theoretical section, in which I try to discover how the school library can contribute to the cultural education of students. It also consists of an empirical section, in which I try to sketch a picture of the school librarians' perception of their own practice as cultural intermediaries. Initially in this paper I will present one small part of the theory and then I will consider one of the questions from a questionnaire used in a survey carried out in the autumn of 2001: activities organised to process culture through the school library.
\end{abstract}

\section{It Is All About Culture}

Danish School libraries have been undergoing rapid changes in recent years. In compliance with the new legislation of 1993 the object and identity of the school libraries have changed. The legislation concerning the Danish Folkeskole (the state school) stipulates that the school library has to function as a 'pedagogic service centre'. The use of that term is an indication of a wish to consolidate the pedagogical functions of the school library as a part of the general activities of the school. The involvement between the school and the school library must be reinforced and developed in such a way that the school library becomes an extension of the classroom. With the new legislation the processing of culture through the school and the school library has also become very important. Emphasis is placed on students having to be conversant with Danish culture.

But what is culture? This is not an easy question to answer. The concept of culture is very difficult to define, and at this juncture I shall not venture into a long account of the extent of its significance or of the many facets of the concept, but only mention that my own understanding has its root in the theory of cultural psychology that considers perception, cognition, values etc. as inseparable parts of culture. The American psychologist Jerome Bruner states his views on the relationship between consciousness and culture in the following manner:

"Culture, then though itself man-made, both forms and makes possible the workings of a distinctively human mind. On this view, learning and thinking are always situated in a cultural setting and always dependent upon the utilization of cultural resources" (1996, p.4) 
Thus culture constitutes a mental toolbox, a number of ways to construe one's reality; it is like a pair of mental contact lenses through which we contemplate the world and ourselves.

How, then, will students' minds become 'culturalized' in the school library? How will they get their Danish "contact lenses"?

One answer is: by just being there and being part of the school library's everyday routine. The point is that all of the school library's work can be seen as culturally didactic. The school library has its own particular culture: The school librarian chose the range of printed stories on the shelves that are made accessible to lenders. There are films, CD-Roms, and many other products that are made available for use. Frequently there is art hanging on the walls. Cultural arrangements are put on in the form of theatre performances, visits by authors, the showing of films and much more. School libraries are active in particular ways and occasionally there are explicit rules for these activities. All this culture at the school library is arranged with an educational purpose; the intention is to influence and develop schoolchildren's minds with respect to culture. For that reason it is cultural didactics in practice. I was first introduced to the term 'cultural didactics' by the university lecturer Bernard Eric Jensen at a conference at The Danish University of Education in the autumn of 2000. Here 'cultural didactics' was defined as the didactics relating to the promotion of culture. It is a didactics with both descriptive and normative aspects, in that it seeks to describe and explain how the cultured mind is formed and functions, and it discusses in what way the cultured mind ought to be developed. The term 'cultured mind' indicates that the human mind is formed by the culture it is a part of.

\section{The Narrative}

A special feature of the processing of culture is the narrative. In schools the library is the central provider of the narrative. It actively promotes the main narratives in the culture's literary canon, and at the same time the school library is often the place where schoolchildren can experiment in various creative ways with completed narratives - and, importantly, also be productive narrators in a variety of different media.

In addition, the narrative is also a tool in classroom situations in the library, when, for example, pupils work together on and consider the use of literary devices.

The values of the culture, ways of thinking etc. are incorporated in narratives and transmitted by narratives. And human consciousness is organised as narratives, too.

This is a viewpoint that has been expressed by Jerome Bruner, Kenneth Gergen, Klaus P. Mortensen and Mark Turner, among others. Turner (1996) makes the point quite forcefully: "The story is a basic mental principle. Most of our experience, our knowledge, and our thinking is organised as stories". We are constantly creating stories about our lives and the relations we enter into: about the commuter train home from work, the time the elderly lady fainted, the quarrel with the boss and plans for the impending holidays. The narrative is an account, hence it is used consciously by people to bring structure to the experiences and knowledge they have about themselves and to the world they live in. The narrative is used to make sense of our lives, to understand the world around us and to make ourselves understood by others. As the narrative is determined by culture, it is self evident that humans, exposed to the narratives of a given culture, will come into close contact with 
the basic foundations of this culture; they become familiar with this particular culture's particular way of making sense. This may influence thinking. The way people think is expanded and developed in the encounter with other narratives: When your comprehension of the world clashes with divergent conceptions, you create the narrative in an effort to grasp the discrepancy. By thinking in terms of narratives, new stories are created, and these new stories are incorporated into existing cognitive structures. In this way narrative thinking will transform the contents and the organisation of human knowledge and thinking in its way of contemplating and interpreting the world.

\section{A Model of the Cultural Didactics Field}

I have constructed this model to demonstrate the relations between culture, narration and consciousness:

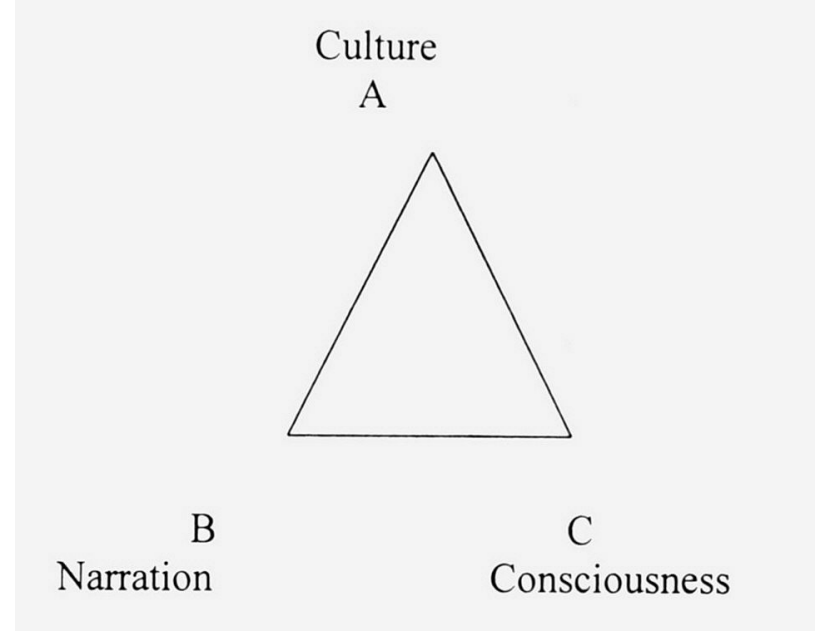

The main statement of the model is:

Culture is fundamental to human consciousness, to literature and accordingly to the narrative. Consciousness is organized as narratives. And human consciousness is formed in the encounter with literary texts and other narratives. The model, which has to be seen as a model of the cultural didactics field, has two levels in my project: a theoretical one (level 1) and an empirical one (level 2). In the following I will examine each axis separately and at both levels.

\section{Level 1: the theoretical level}

\section{The $A B$ axis: the connection between culture and the narrative}

This axis includes theories dealing with the links between culture and the narrative. Thus one dimension of this axis is theories about the fact that the narrative can be seen as an expression of culture and that the narrative is the bearer of the culture's values and modes of thinking. There is also an implication here that there will always be value judgements and evaluation taking place of various narratives in a culture, including the media in which the narratives appear. Young people judge certain narratives differently from school librarians.

\section{The AC axis: the connection between culture and consciousness}

This axis includes theories dealing with the links between culture and consciousness. Thus it includes theoretical reflections about how the human mind is formed by the culture. The axis also includes reflections and decisions about in what way the cultured mind ought to be developed. 


\section{The $B C$ axis: the connection between the narrative and consciousness}

This axis includes theories dealing with the links between the narrative and consciousness. This axis is the main focus in my use of the model, and it is also this axis that is most complex; it consists of several layers at the level of theory:

- the theory of how thinking is itself organised as narratives

- the theory of how the formative processes take place in the encounter between the consciousness and the narrative.

- the theory of and empirical surveys of specified uses by the consciousness of narratives and media.

- A practical dimension comprising a) an encounter between a single consciousness and fictional narratives in various media b) the interaction between the single consciousness and other consciousnesses with the narrative as the medium c) an encounter between a single consciousness and its own narratives in thinking and metacognition.

The practical dimension of my project concerns itself with the $\mathrm{BC}$ axis, as the focus is the formation of the consciousness in its encounter with the narrative in the school library. On the other two axes there are a number of reflections and conclusions concerning the teaching of culture, which underpin how the practical dimension on the $\mathrm{BC}$ axis is set up. I should mention that the model can be perceived and used in other ways, so that it may operate with the $\mathrm{AB}$ axis and the $\mathrm{AC}$ axis as practical dimensions.

\section{The projection of the axes onto each other}

At a theoretical level the aim of the model is to have interplay between the axes. My focus is, as I have already said, the $\mathrm{BC}$ axis and in order to comprehend as best I can and create an image of how cultural education takes place, here I have to project the $\mathrm{AB}$ and $\mathrm{AC}$ axes onto this axis. On its own the $\mathrm{BC}$ axis has, of course, no cultural dimension; it only comes into existence with the projection of the other two axes.

\section{The empirical level}

My empirical methods do not include studies of practice. I do not go out into the field like an anthropologist or an ethnographer and observe what actually happens. So I do not study directly the teaching activities in action in the school library, how new purchases are dealt with, what rules are applied in the library, etc. I ask the school librarians about these things. The empirical date I collect is thus the school librarians' interpretation of their practice and the perceptions, attitudes and thinking behind the practice.

\section{The $A B$ axis:}

On this axis one finds the librarians' perceptions of, attitudes towards and assessment of materials - various narratives and media from the school library. Some questions to consider on this axis are: Are the criteria for the choice of material explicit or implicit? To what extent does the individual librarian share these criteria? What materials are given priority currently and how? And what input do librarians have in the choice of material?

\section{The $A C$ axis:}

This axis includes the school librarians' thinking on and reasoning for the content of the cultural development process, their ideas of how culture can best be acquired and mediated, their ideas of what the tasks for the school and school librarians are. 


\section{The BC axis:}

This axis reflects the organization of practice: the management of the encounter between schoolchildren and narratives. As I have already said, it is not the empirical practice that is examined, but the librarians' interpretation of their practice. What activities do they say take place and to what extent?

\section{The projection of the axes}

Also at this level there will be a projection of axes onto each other. On the AB and $\mathrm{AC}$ axes a number of cultural didactics decisions are made and choices are made on the basis of reflections in this area. These decisions and choices are projected onto the $\mathrm{BC}$ axis and have implications here for the management of practice. In practical terms it is not possible to separate the $\mathrm{AB}$ and $\mathrm{AC}$ axes. When the school librarian on the $\mathrm{AB}$ axis takes a decision about what new materials have to be bought in it is done with an eye on cultural development aims. These aims, and the thinking behind them, belong to the AC axis. Accordingly it is also true, of course, that when the school librarian on the AC axis reflects and takes decisions it will involve the $\mathrm{AB}$ axis. These two axes can therefore only be looked at separately on an abstract level. The reality of the cultural didactics field is that the axes are in permanent interaction.

\section{A Survey Involving 250 Danish School Librarians}

In Autumn 2001 I carried out a quantitative survey involving 250 Danish school librarians. As documented, the purpose was to examine the questions asked in the model. In this paper I will present the results of the 'activities for promoting culture':

First of all I asked the school librarians to what extent they regarded the reading of books, journals, newspapers, watching television programmes, e-mailing, telling and writing stories etc. as a necessity for the promotion of culture. Secondly I asked them to what extent they thought these activities were tasks the school library should carry out. And thirdly I asked them to what extent the activities were actually taking place in their school library.

The three most popular activities were the following: reading books, having books read aloud and using computers to search for information. Almost all of those asked in the survey thought that these activities were, to a very great or great extent, necessary for the process of promoting culture. The results were $97.7 \%, 97.8 \%$ and $94.4 \%$ respectively. There is not so much unanimity with regards to whether these activities fall within the responsibility of the school library. Almost all of those asked (98.3\%) still thought that it was, to a great extent, the library's responsibility to ensure that pupils read, while only $77.3 \%$ considered that it was the library's responsibility to read aloud to pupils. Most librarians saw the computer, as a tool for searching for information, as more important than the teacher librarian reading aloud. $91.4 \%$ thought that computers were part of the library's responsibility. An almost identical picture emerged when librarians were asked what actually happened in the library. Mostly schoolchildren read books and used the computers to search for information. $90.7 \%$ and $88.6 \%$ thought that these activities actually took place to a very great or great extent. By contrast, only half said that teachers read to pupils to the same extent, while $30.2 \%$ said that teachers read to pupils to some extent. 
Table 1

Pupils read books. Percentage of total.

\begin{tabular}{|l|l|l|l|}
\hline & $\begin{array}{l}\text { Generally necessary in } \\
\text { order to transmit } \\
\text { culture }\end{array}$ & $\begin{array}{l}\text { The school } \\
\text { library's } \\
\text { responsibility }\end{array}$ & $\begin{array}{l}\text { Actually happens in } \\
\text { the school library }\end{array}$ \\
\hline $\begin{array}{l}\text { To a very great or great } \\
\text { extent }\end{array}$ & $97.7 \%$ & $98.3 \%$ & $90.7 \%$ \\
\hline To some extent & $2.3 \%$ & $1.7 \%$ & $9.3 \%$ \\
\hline To a small extent & $0.0 \%$ & $0.0 \%$ & $0.0 \%$ \\
\hline $\begin{array}{l}\text { To a very small extent } \\
\text { or not at all }\end{array}$ & $0.0 \%$ & $0.0 \%$ & $0.0 \%$ \\
\hline
\end{tabular}

Table 2

School librarians read to pupils. Percentage of total.

\begin{tabular}{|l|l|l|l|}
\hline & $\begin{array}{l}\text { Generally necessary in } \\
\text { order to transmit } \\
\text { culture }\end{array}$ & $\begin{array}{l}\text { The school } \\
\text { library's } \\
\text { responsibility }\end{array}$ & $\begin{array}{l}\text { Actually happens in } \\
\text { the school library }\end{array}$ \\
\hline $\begin{array}{l}\text { To a very great or great } \\
\text { extent }\end{array}$ & $97.8 \%$ & $77.3 \%$ & $50 \%$ \\
\hline To some extent & $2.2 \%$ & $18.6 \%$ & $30.2 \%$ \\
\hline To a small extent & $0.0 \%$ & $1.7 \%$ & $8.1 \%$ \\
\hline $\begin{array}{l}\text { To a very small extent } \\
\text { or not at all }\end{array}$ & $0.0 \%$ & $2.4 \%$ & $11.7 \%$ \\
\hline
\end{tabular}

Table 3

Pupils use the computer to search for information (Internet, CD-Rom). Percentage of total.

\begin{tabular}{|l|l|l|l|}
\hline & $\begin{array}{l}\text { Generally necessary in } \\
\text { order to transmit } \\
\text { culture }\end{array}$ & $\begin{array}{l}\text { The school } \\
\text { library's } \\
\text { responsibility }\end{array}$ & $\begin{array}{l}\text { Actually happens in } \\
\text { the school library }\end{array}$ \\
\hline $\begin{array}{l}\text { To a very great or great } \\
\text { extent }\end{array}$ & $94.4 \%$ & $91.4 \%$ & $88.6 \%$ \\
\hline To some extent & $4,9 \%$ & $6,7 \%$ & $8,9 \%$ \\
\hline To a small extent & $0.7 \%$ & $1.2 \%$ & $0.6 \%$ \\
\hline $\begin{array}{l}\text { To a very small extent } \\
\text { or not at all }\end{array}$ & $0.0 \%$ & $0.7 \%$ & $1.9 \%$ \\
\hline
\end{tabular}

The picture was rather more varied when the librarians were asked about the pupils' own writing and about drama in the school library. The general opinion was that these activities were important for promoting culture but they were not seen as the responsibility of the school library and nor was it something that happened very often. Accordingly $88.9 \%$ of all the librarians considered that pupils needed to write stories themselves as part of the 'culturalisation' process. However, $36.3 \%$ of the school librarians also said that pupils never 
wrote stories in the school library. Nevertheless the school library could be regarded as a very suitable place. There is room for schoolchildren to discuss, find inspiration through reading books and there are computers to write stories on.

Table 4

Pupils write stories, also together with and in dialogue with other children and adults.

\begin{tabular}{|l|l|l|l|}
\hline & $\begin{array}{l}\text { Generally necessary in } \\
\text { order to transmit } \\
\text { culture }\end{array}$ & $\begin{array}{l}\text { The school } \\
\text { library's } \\
\text { responsibility }\end{array}$ & $\begin{array}{l}\text { Actually happens in } \\
\text { the school library }\end{array}$ \\
\hline $\begin{array}{l}\text { To a very great or great } \\
\text { extent }\end{array}$ & $88.9 \%$ & $16.8 \%$ & $9.0 \%$ \\
\hline To some extent & $10.5 \%$ & $41.6 \%$ & $27.0 \%$ \\
\hline To a small extent & $0.6 \%$ & $21.1 \%$ & $27.7 \%$ \\
\hline $\begin{array}{l}\text { To a very small extent } \\
\text { or not at all }\end{array}$ & $0.0 \%$ & $20.5 \%$ & $36.3 \%$ \\
\hline
\end{tabular}

The same is true for drama. The school library could contribute here by arranging theatre visits outside school and by inviting actors to the school library. The library is the place where schoolchildren can work with a play in a variety of ways: readings, analyses, dramatizations, and making a display around it. But these are activities that have not really made an impact yet with Danish school librarians: only $37.2 \%$ saw it as the librarian's job to arrange theatre performances for their pupils and 38.3\% said that there was never any drama in their library. Even fewer offered pupils the chance to act in a play at their library: $56.4 \%$ answered that pupils never acted in the library and only $2.5 \%$ took part in drama productions to any great extent.

Table 5

Pupils see drama

\begin{tabular}{|l|l|l|l|}
\hline & $\begin{array}{l}\text { Generally necessary to } \\
\text { transmit culture }\end{array}$ & $\begin{array}{l}\text { The school } \\
\text { library's } \\
\text { responsibility }\end{array}$ & $\begin{array}{l}\text { Actually happens in } \\
\text { the school library }\end{array}$ \\
\hline $\begin{array}{l}\text { To a very great or great } \\
\text { extent }\end{array}$ & $84.0 \%$ & $37.2 \%$ & $12.9 \%$ \\
\hline To some extent & $13.6 \%$ & $40.1 \%$ & $29.4 \%$ \\
\hline To a small extent & $2.4 \%$ & $16.3 \%$ & $19.4 \%$ \\
\hline $\begin{array}{l}\text { To a very small extent } \\
\text { or not at all }\end{array}$ & $0.0 \%$ & $6.4 \%$ & $38.3 \%$ \\
\hline
\end{tabular}


Table 6

Pupils take part in theatre productions

\begin{tabular}{|l|l|l|l|}
\hline & $\begin{array}{l}\text { Generally necessary in } \\
\text { order to transmit } \\
\text { culture }\end{array}$ & $\begin{array}{l}\text { The school } \\
\text { library's } \\
\text { responsibility }\end{array}$ & $\begin{array}{l}\text { Actually happens in } \\
\text { the school library }\end{array}$ \\
\hline $\begin{array}{l}\text { To a very great or great } \\
\text { extrent }\end{array}$ & $80.9 \%$ & $80 . \%$ & $2.5 \%$ \\
\hline To some extent & $16.7 \%$ & $32.9 \%$ & $17.7 \%$ \\
\hline To a small extent & $2.4 \%$ & $27.3 \%$ & $23.4 \%$ \\
\hline $\begin{array}{l}\text { To avery small extent or } \\
\text { not at all }\end{array}$ & $0.0 \%$ & $31.5 \%$ & $56.4 \%$ \\
\hline
\end{tabular}

\section{Conclusion}

My survey shows that school librarians by and large see most activities as having significance for the promotion of culture. However, not so many see it as the school library's responsibility to organize these activities and there are not so many of these activities actually taking place in the school library. There continues to be a perception that the school library is a passive service facility. Nevertheless there are indications that school librarians will have to be a lot more active in their roles as mediators of culture. At the same time they will have to think in different ways concerning the organization of their practice. Indeed it is imperative if the school library is intended to be an exciting place, a place where pupils learn and where they learn more than they would have done otherwise. Specifically, this means, for example, that the range of activities will have to be made broader. It means, for example, that pupils will have to have story readings, presentations of art, theatrical productions - and themselves become active participants in culture by having the opportunity to tell stories, work with art and act in plays in the school library. In this way the school library will become a place where pupils are at home with our culture's literary canon of narratives and where they have the space to develop their own narratives. And it thereby becomes a place where they learn the distinctive characteristics of our culture in a fruitful interaction with their own ways of construing meaning.

\section{References}

Bishop, Russel and Ted Glynn (1999): Culture Counts. Changing Power Relations in Education. Dunmore Press.

Bruner, Jerome (1996). The Culture of Education. Harward University Press.

Chaiklin, Seth (2001): The Theory and Practice of Cultural-Historical Psychology. Aarhus University Press.

Gergen, Kenneth (1997): Realities and Relationships: Soundings in Social Construction. Harward University Press. 
Kruger, Ann Cale, Michael Tomasello and Hilary Horn Ratner: Cultural learning in: Behavioral and Brain Sciences (1993) 16, p. 495-552.

Kruger, Ann Cale and Michael Tomasello (1996): Cultural learning and Learning Culture in: Olsen, David R. And Nancy Torrance (ed.): The Handbook of Education and Human Development. Cambridge, Mass. Blackwell Publishers.

Mortensen, Klaus P. (1998): Litteratur er padagogik [Literature is socialization]. Dansk $4 / 1998$.

Mortensen, Klaus P. (2000): Spejlinger. Litteratur og refleksion [Literature and reflection] Forlaget Spring.

Polkinghorne, Donald E. (1988): Narrative Knowing and the Human Sciences. State University of New York.

Sarbin, Theodore R. (1986): Narrative Psychology. The Storied Nature of Human Conduct. Praeger Publishers.

Turner, Mark (1996). The Literary Mind. Oxford University Press.

Thavenius, Jan (1995). Den motsägelsesfulla bildningen [An Education of Contradictions].

The Danish Ministry of Education (1993): Folkeskoleloven [Primary Education Act].

Todd, Ross (2001): Transitions for preferred futures of school libraries. Keynote paper, IASL conference 2001.

Weinreich, Torben (2000): Children's Literature - Art or Pedagogy? Roskilde University Press. 